FIU Law Review

Fall 2015

\title{
Provocative Speech in French Law: A Closer Look at Charlie Hebdo
}

Asma T. Uddin

The Becket Fund for Religious Liberty

Follow this and additional works at: https://ecollections.law.fiu.edu/lawreview

Part of the Other Law Commons

Online ISSN: 2643-7759

\section{Recommended Citation}

Asma T. Uddin, Provocative Speech in French Law: A Closer Look at Charlie Hebdo, 11 FIU L. Rev. 189 (2015).

DOI: https://dx.doi.org/10.25148/lawrev.11.1.14

This Article is brought to you for free and open access by eCollections. It has been accepted for inclusion in FIU Law Review by an authorized editor of eCollections. For more information, please contact lisdavis@fiu.edu. 


\title{
Provocative Speech in French Law: A Closer Look at Charlie Hebdo
}

\author{
Asma T. Uddin ${ }^{*}$
}

\section{INTRODUCTION}

At 11:30 a.m. on January 7, 2015, brothers Cherif and Said Kouachi, masked, dressed in black, and armed with Kalashnikov assault rifles, approached the offices of Charlie Hebdo, a satirical French magazine. They forced one of the magazine's cartoonists to enter the code to the newsroom door. Upon entering the room, the men opened fire and killed the editor, Stephane Charbonnier, and four Charlie Hebdo cartoonists along with several others. The gunmen shouted, "We have avenged the Prophet Muhammad" and "God is Great" in Arabic as they called out the names of the journalists. The gunmen escaped by car.

During the chase, Amedy Coulibaly, a friend of the two terrorists, killed a policewoman in Montrouge, ${ }^{1}$ and on January 9, took several people hostage at a kosher supermarket at Porte de Vincennes. He threatened to kill the hostages unless the Kouachi brothers were allowed to go free. ${ }^{2}$ At around 5:00 p.m. that day, the police stormed the supermarket and killed Coulibaly, while another operation launched at the same time killed the Kouachi brothers, who were hiding in a printing firm in Dammartin-enGoele. $^{3}$

Both individuals and the French government responded zealously to the attack on Charlie Hebdo. Social media became saturated with the hashtag \#JeSuisCharlie, or \#IAmCharlie, as French citizens and individuals abroad rushed to show solidarity with the cartoonists of Charlie Hebdo and the cause of freedom of speech. The French government commenced "aggressive enforcements" of Law No. 2014-1353 of November 13, 2014, an anti-terrorism law that was rarely used until the weeks prior to the

Asma T. Uddin is Counsel at The Becket Fund for Religious Liberty and the founding Editorin-Chief of altmuslimah.com.

1 Peter Allen, Gunman Who Shot Dead a Paris Policewoman the Day after the Charlie Hebdo Attack IS Linked to the Killers Who Gunned Down Magazine Staff, Say Police, DAILYMAIL.COM (Jan. 9 , 2015), www.dailymail.co.uk/news/article-2903347/Gunman-shot-dead-Paris-policewoman-day-CharlieHebdo-attack-linked-killers-gunned-magazine-staff-say-police.html.

2 Mohamed Madi et al., As It Happened: Charlie Hebdo Attack, BBC, www.bbc.com/news/live/ world-europe-30710777 (last visited July 27, 2015).

3 Harriet Alexander, Paris Attacks: Special Forces Hit Amedy Coulibaly with 40 Bullets, THE TELEGRAPH (Jan. 11, 2015, 9:49 PM), www.telegraph.co.uk/news/worldnews/europe/france/11338 925/ Paris-attacks-Special-forces-hit-Amedy-Coulibaly-with-40-bullets.html. 
attacks, against anyone who spoke out against the Charlie Hebdo cause. ${ }^{4}$ Among those prosecuted for their speech was Dieudonné M'Bala M'Bala, a French comedian, who was arrested for "defending terrorism" in a Facebook status that read, "Tonight, as far as I'm concerned, I feel like Charlie Coulibaly." The statement is a combination of the slogan "Je suis Charlie" ("I am Charlie") and "Amedy Coulibaly," the name of the gunman who terrorized the kosher supermarket, and appears to imply sympathy with the terrorists. He was fined $\$ 37,000$. $^{5}$

Various commentators and scholars have pointed out the double standard in the French government's treatment of speech, especially in the wake of the Charlie Hebdo attacks. The New Yorker noted that "[t]he juxtaposition of ... the celebration of a magazine that routinely publishes cartoons considered blasphemous and offensive by many of the world's Muslims and the muscular prosecution of a relentlessly provocative black comedian" made the hypocrisy glaringly obvious. ${ }^{6}$ Similarly, Jonathan Turley reflected in the Washington Post about the spontaneous rally in support of Charlie Hebdo after the attacks: "[O]ne could fairly ask what they were rallying around. The greatest threat to liberty in France has come not from the terrorists who committed such horrific acts this past week but from the French themselves, who have been leading the Western world in a crackdown on free speech."

Indeed, the French government has a history of using its speech laws to curtail the speech of journalists, comedians, celebrities, and ordinary citizens alike. That same tendency of restricting speech came into play in the wake of the Charlie Hebdo attacks, when the French government simultaneously punished critics for their speech and glorified Charlie Hebdo as a symbol of freedom of speech.

At the core of the French double standard is its inconsistent distinction between protection and punishment of provocative speech. In Part I, this paper will look briefly at how international law treats provocation, in particular, Articles 19-20 of the International Covenant on Civil and

4 Doreen Carvajal \& Alan Cowell, French Rein In Speech Backing Acts of Terror, N.Y. TIMES (Jan. 15, 2015), www.nytimes.com/2015/01/16/world/europe/french-rein-in-speech-backing-acts-ofterror.html?_r=0.

5 Eleanor Beardsley, The French Debate: Free Speech Versus Hate Speech, NPR (Feb. 10, 2015), www.npr.org/sections/parallels/2015/02/10/384959376/the-french-debate-free-speech-versus-hate -speech.

6 Alexander Stille, Why French Law Treats Dieudonné and Charlie Hebdo Differently, NEw YORKER (Jan. 15, 2015), www.newyorker.com/news/news-desk/french-law-treats-dieudonne-charliehebdo-differently.

7 Jonathan Turley, The Biggest Threat to French Free Speech Isn't Terrorism. It's the Government, WASHINGTON POST (Jan. 8, 2015), www.washingtonpost.com/opinions/what-it-means-tostand-with-charlie-hebdo/2015/01/08/ab416214-96e8-11e4-aabd-d0b93ff613d5_story.html. 
Political Rights (ICCPR). Then, Part II will look at the ways French speech law embodies the aforementioned double standard because of its failure to adopt the international standard on provocation. The paper will conclude by advocating for a more uniform, more protective approach to speech-one that will bring French law into conformity with international law.

\section{PART I}

\section{International Law on Provocative Speech}

The ICCPR is an international human rights treaty adopted by the U.N. General Assembly in $1976 .{ }^{8}$ Two Articles pertain directly to the freedom of speech. Article 19 delineates "the right to hold opinions without interference" and "the right to freedom of expression." Article 19(3) states that these rights are "subject to certain restrictions, but these shall only be such as are provided by law and are necessary: (a) For respect of the rights or reputations of others; (b) For the protection of national security or of public order (ordre public), or of public health or morals." Article 20(2) of the ICCPR specifies further limits for free speech, prohibiting "any propaganda" and "any advocacy of national, racial or religious hatred that constitutes incitement to discrimination, hostility or violence." 10

In reference to the restrictions on speech in Article 19(3), General Comment No. 34 prepared by the U.N. Human Rights Committee highlights that:

When a State party invokes a legitimate ground for restriction of freedom of expression, it must demonstrate in specific and individualized fashion the precise nature of the threat, and the necessity and proportionality of the specific action taken, in particular by establishing a direct and immediate connection between the expression and the threat. ${ }^{11}$

This Comment is significant as it notes the need for a "specific" threat that is "direct[ly] and immediate[ly]" tied to the expression. In other words, expression cannot be limited on the basis of a potential threat. Instead, the limitation is akin to the "incitement to imminent violence" standard in U.S. jurisprudence. In Brandenburg v. Ohio, the U.S. Supreme Court found that the government could not prohibit speech "except where such advocacy is

8 FAQ: The Covenant on Civil \& Political Rights (ICCPR), ACLU, www.aclu.org/faq-covenantcivil-political-rights-iccpr (last updated Apr. 2014).

9 U.N. GAOR, International Covenant on Civil and Political Rights, UNITED NATIONS (Dec. 16, 1966), www.refworld.org/docid/3ae6b3aa0.html.

$10 \quad I d$.

11 U.N. HRC Gen. Comment No. 34, 102nd session, July 11-29, 2011, CCPR/C/GC/34 (Sept. 12, 2011). 
directed to inciting or producing imminent lawless action and is likely to incite or produce such action." 12

ICCPR Article 20's limits on speech should be interpreted in a similar vein. General Comment No. 34 notes that:

Articles 19 and 20 are compatible with and complement each other. The acts that are addressed in article 20 are all subject to restriction pursuant to article 19, paragraph 3. As such, a limitation that is justified on the basis of article 20 must also comply with article 19, paragraph $3 .^{13}$

A 2010 study prepared for the Office of the High Commissioner for Human Rights (OHCHR) echoes this position. ${ }^{14}$ According to the study, Article 20, in practice, requires courts to evaluate speech based on a series of tests. If the speech in question meets the standard of "the most severe and deeply felt form of opprobrium," has "specific intent," contains a "direct and/or explicit call to commit the action-discrimination, hostility or violence," is directed at a general public or individuals in a public space, leads to imminent harm, and is "very likely to result in criminal action and harm," "then the speech can be restricted. However, if the speech in question does not pass even one of these tests, it could not be legitimately prohibited. $^{16}$

The listed criteria are similar to the distinction drawn by the Brandenburg Court, which held that "the mere abstract teaching... of the moral propriety or even moral necessity for a resort to force and violence" constitutes protected speech, whereas "preparing a group for violent action and steering it to such action" is not. ${ }^{17}$ The first category of speech falls within the ambit of provocation, whereas the latter constitutes incitement to imminent violence.

A speaker provokes violence by engaging in speech that causes a listener to be "so outraged that [he feels] compelled to riot and commit mayhem. ${ }^{" 18}$ In contrast, a speaker incites violence when he or she intends to produce imminent lawless action and is likely to produce such action.

12395 U.S. 444, 447-49 (1969).

13 Gen. comment No. 34, supra note 11, ๆ 50, at 12-13.

14 Barbora Bukovska et al., Towards an Interpretation of Article 20 of the ICCPR: Thresholds for the Prohibition of Incitement to Hatred, art. 19 at 21, www.ohchr.org/Documents/Issues/Expression/ ICCPR/Vienna/CRP7Callamard.pdf.

$15 I d$.

16 Id. at 17.

17 Brandenburg, 395 U.S. at 448.

18 Asma Uddin, Free Speech and Public Order Exceptions: A Case for the U.S. Standard 131 (2015) (unpublished manuscript) (on file with Brigham Young University Law Review) (quoting Professor Robert C. Post). 
Measured against the OHCHR's criteria, provocation, unlike incitement, is protected speech because it does not involve "specific intent," a "direct and/ or explicit call" to violence or crime, or the possibility of leading to "imminent harm." As such, a state cannot, in accordance with international law, limit speech amounting to mere provocation.

The U.N.'s independent human rights experts support this interpretation of international law. In a 2008 statement joined by other independent experts, then-U.N. Special Rapporteur on Freedom of Expression, Frank La Rue, proclaimed that, "Restrictions on freedom of expression ... should never be used to protect particular institutions, or abstract notions, concepts or beliefs, including religious ones." ${ }^{19}$ In 2006, then-U.N. Special Rapporteur for Freedom of Religion, Asma Jahangir, stated:

the right to freedom of religion or belief as enshrined in relevant international legal standards, does not include the right not to have a religion or belief that is free from criticism or ridicule ... defamation of religions may offend people and hurt their religious feelings but it does not necessarily or at least directly result in a violation of their rights, including the right to freedom of religion. ${ }^{20}$

The U.N.'s independent human rights experts have advocated for a line drawing that does not restrict speech that merely criticizes religious beliefs, or is offensive to people of particular faiths. Instead, the human rights experts view offensive and critical speech as provocation, a category of speech protected under the ICCPR.

The experts have maintained this clarity despite a protracted battle over the precise standard. In 1999, Pakistan proposed a resolution at the U.N. General Assembly on behalf of the organization of the Islamic Conference (OIC) that sought to condemn "defamation of religion"; the goal of the so-called Defamation of Religions Resolution was to "protect religion generally and Islam specifically from 'hate speech",21 by urging states to "take all appropriate measures to combat hatred, discrimination, intolerance and acts of violence, intimidation and coercion motivated by religious intolerance, including attacks on religious places, and to encourage understanding, tolerance and respect in matters relating to

19 Evelyn Aswad, To Ban or Not to Ban Blasphemous Videos, 44 GEO. J. INT’L L. 1313, 1326 (2013).

$20 \quad$ Id. at 1327.

21 Asma Uddin \& Haris Tarin, Rethinking the "Red Line": The Intersection of Free Speech, Religious Freedom, and Social Change, BROOKINGS InSTITUTION, Nov. 2013, at 1-2, www.brookings. edu/ /media/Research/Files/Papers/2013/11/us\%20islamic\%20world\%20forum\%20publications/Free\% 20Speech_English_Web.pdf. 
freedom of religion or belief." 22 The Resolution had many flaws, as it "accorded human rights to religion/ideology rather than to individuals," and "sought to limit the speaker rather than the violent actor." 23

Over the years, there was a decline in support for the Resolution. Finally, in March of 2011, the OIC and the U.N. Human Rights Council made significant progress in recognizing the fundamental right of human expression. The OIC worked closely with the United States to reach consensus on a new resolution that entirely foregoes the "defamation of religions" language. Rather than protecting religions, the resolution protects religious persons. U.N. Human Rights Council resolution 16/18, titled "Combating Intolerance, Negative Stereotyping and Stigmatization of, and Discrimination, Incitement to Violence, and Violence against Persons Based on Religion or Belief," condemns "any advocacy of religious hatred against individuals that constitutes incitement or discrimination, hostility or violence." Instead of sanctioning broad limits on speech in order to prevent the "defamation of religion," Resolution 16/18 interpreted ICCPR Article 20(2) to proscribe only "incitement to imminent violence based on religion or belief," 24 and suggested concrete steps "to foster a domestic environment of religious tolerance, peace and respect." 25

Resolution 16/18 thus brought the international consensus back to the incitement standard for freedom of expression, a standard that does not restrict provocative speech.

\section{PART II}

\section{The French Double Standard}

Part I outlined the current international standard on provocative speech. Part II will examine French speech laws and the ways in which France's failure to comply with the international standard leads to contradictory speech restrictions.

\section{A Brief Overview of French Free Speech Law}

"[C]riminalization of anti-religious speech forms part" of France's "human rights tradition," with speech restricted in the name of public order ${ }^{26}$ Article 10 of France's DEClaRATION OF THE Rights OF MAN

22 Defamation of Religions, H.R.C. Res. 1999/82 (Apr. 30, 1999).

23 Uddin \& Tarin, supra note 21, at 2.

24 Int'l Covenant on Civil and Political Rights art. 20 (2), Dec. 19, 1966, U.N.T.S. 171.

25 Robert C. Blitt, Defamation of Religion: Rumors of Its Death Are Greatly Exaggerated, 62 CASE W. RES. L. REV. 347, 361 (2011).

26 Susannah C. Vance, The Permissibility of Incitement to Religious Hatred Offenses Under European Convention Principles, 14 TransNaT'L L. \& CONTEMP. ProBS. 201, 221 (2004). 
states that " $[\mathrm{n}] \mathrm{o}$ one shall be disquieted on account of his opinions, including his religious views, provided their manifestation does not disturb the public order established by law." ${ }^{27}$ The Declaration inspired the LAW OF JULY $29,1881,{ }^{28}$ the "backdrop" ${ }^{29}$ upon which more recent anti-racism laws have been framed, prohibited any public speech that provoked a crime or an attempted crime. ${ }^{30}$ Nearly sixty years later, the décret Marchandeau, an amendment to the LAW OF JULY 29, 1881, enabled individuals to bring charges if they "had been named personally in a racist invective." It also allowed state prosecutors to "initiate legal proceedings in cases where a whole group was implicated." 31 In practice, however, the state rarely prosecuted under the décret Marchandeau, and courts were reluctant to apply the law outside the context of public disorder. ${ }^{32}$

In the years to follow, French civil rights organizations began to push for stricter laws against racist speech. ${ }^{33}$ The push was partly based on increasing concerns about racism resulting from an influx of foreign workers, and partly on France's signing and ratifying of the U.N. International Convention on the Elimination of Racial Discrimination. ${ }^{34}$ These proposed laws, eventually combined into the PLEVEN LAW OF 1972 (which amended the LAW OF JULY 29, 1881), banned "hate speech, making racial defamation and provocation to racial hatred or violence punishable by criminal law." ${ }^{\prime 35}$ More specifically, it proscribed "speech in both public and non-public places... that 'provoke discrimination, hatred or violence against a person or a group of people' on account of ethnicity, nationality, race, or religion. ${ }^{, 36}$ In recent decades, the PLEVEN LAW has been used in

27 Declaration Des Driots de L'Homme et Du Citoyen [Declaration of the Rights of Man and of the Citizen], Aug. 26, 1789 (Fr.), translated in The Avalon Project (Yale Law School, Lilian Goldman Library).

28 Prior to 1881, French free speech law was complex and unclear. The Law of July 29, 1881 served to replace this jurisprudence. RAYMOND KUHN, THE MEDIA IN FRANCE, 47-49 (1994).

29 Vance, supra note 26, at 222.

30 Loi de 29 juillet 1881 sur la liberte de la presse [Law of July 291881 on Freedom of the Press] LEGIFRANCE.GOUV.FR, www.legifrance.gouv.fr/affichTexte.do?cidTexte=LEGITEXT00000607 $0722 \&$ dateTexte $=$ vig.

31 Karen Bird, Racist Speech or Free Speech? A Comparison of the Law in France and the United States, 32.4 Comp. PoL. 399, 408 (2000).

32 For example, in the 1971 case, Perroux v. Ministere Public, journalist Christian Perroux was acquitted of racially denigrating speech for his article criticizing Jewish French citizens for maintaining allegiance with Israel. The tribunal found that, although Perroux's statements were "insulting and injurious ... of a nature to damage the honor and reputation of the targeted persons," the law "was not intended to protect individuals, but to punish agitation against the general public peace." Id. at 417 .

33 Id. at 408.

$34 \quad I d$.

35 Erik Bleich, Race Policy in France, Brookings Institute (May 1, 2001), www. brookings.edu/research/articles/2001/05/france-bleich.

36 Roni Cohen, Regulating Hate Speech: Nothing Customary About It, 15.1 CHI. J. INT’L L. 229 
high-profile cases, with academics, politicians, and movie stars charged under it for inciting racial hatred. ${ }^{37}$

Despite the PLEVEN LAW broad prohibitions, racist speech and hate crimes continued to increase. These crimes, such as a horrific desecration of a Jewish cemetery attributed to a virulently anti-immigrant, anti-Semitic group ${ }^{38}$ led to the adoption, in July of 1990 , of the highly controversial GAYSSOT LAW, which reinforced previous anti-racism laws and made the denial of the Jewish Holocaust a criminal offence. ${ }^{39}$ In 2001, France enacted the TAUBIRA LAW, ${ }^{40}$ which defines the African slave trade as a "crime against humanity." In 2003, it passed the LELLOUCHE LAW, "a stand-alone hate crimes law that enhances penalties for violent crimes motivated by racism." ${ }^{, 41}$ Most recently, on November 13, 2014, the French parliament passed LAW No.2014-1353, which further amended the Law of July 29, 1881.

\section{A Way Forward: Clarifying "Public Order"}

A key concern of all of the aforementioned provisions is maintaining public order. "Hate speech legislation has been justified as a pragmatic response to increasing interethnic tensions, ensuring that diverse groups can cohabit peacefully." 42 Yet, despite the centrality of the concept, the law nowhere defines "public order" (or, ordre public). ${ }^{43}$ French "courts have never articulated a clear definition of public order. Rather, judges seem to take into consideration the public mood at a particular time and place to determine whether a certain expression is likely to cause a dangerous public disruption." ${ }^{44}$ Ordre public has become "a function of time and place."

(2014); Loi de 29 juillet 1881 sur La Liberte de la Presse [Law of July 291881 on Freedom of the Press], LEGIFRANCE.GOUV.FR, www.legifrance.gouv.fr/affichTexte.do?cidTexte=LEGITEXT00000607 $0722 \&$ dateTexte $=$ vig.

37 Vance, supra note 26, at 224.

38 Id.

39 Richard Brody, Injure Raciale, NEw YORKER (Mar. 21, 2011), www.newyorker.com/culture/ richard-brody/injure-raciale.

40 Agnes Poirier, How the Maverick Christiane Taubira Is Transforming French Politics, THE GUARDIAN (Aug. 14, 2013, 11:09 EDT), www.theguardian.com/commentisfree/2013/aug/14/christianetaubira-french-politics.

41 Erik Bleich, Hate Crime Policy in Western Europe: Responding to Racist Violence in Britain, Germany, and France, 51 AM. BEHAV. SCIENTIST 149, 158 (2007).

42 Vance, supra note 26, at 230.

43 Loi 2014-1353 de 13 novembre 2014 renforcant les dispositions relatives a la lutte contre le terrorisme (1) [Law 2014-1353 of November 2014 on Strengthening the Provision on the Fight Against Terrorism], www.legifrance.gouv.fr.

44 Bird, supra note 31, at 407 (emphasis added); Charles W. Mondora, The Public Policy Exception, "The Freedom of Speech, or of the Press" and the Uniform Foreign-Country Money Judgments Recognition Act, 36 HOFSTRA L. REV. 1139 (2008). While the public order exception functions in French law as the "public policy" exception works in American law, the latter is not used by 
And given this fluid definition, the ultimate arbiter of protected versus unprotected speech is "the general will itself." 46

This fluidity naturally creates uncertainty and contradictions, most recently reflected in the French government's response in the wake of the Charlie Hebdo attacks. On one hand, the government upheld Charlie Hebdo as a bastion of free speech, and on the other hand, it brutally cracked down on contrarians like Dieudonné. In the face of this contradictory response, commentators have tried to muster clarity in French free speech jurisprudence.

French media lawyer, Emmanuel Pierrat, drew the line at speech about religion: "in France you can make drawings or speeches against ideology or against religion. The Revolution of 1789 abolished the crime of blasphemy" $"$ and "courts have consistently upheld the legality of speech directed at religions or historical religious figures." ${ }^{48}$ But France's history of singling out religion does not provide a principled basis for continuing to do so, especially since France's approach to speech protections generally has changed so dramatically over time. ${ }^{49}$

Another media lawyer, Mathieu Davy, tried to explain the "double standard" as: "I have the right to criticize an idea, a concept or a religion. I have the right to criticize the powers in my country. But I don't have the right to attack people and incite hate. ${ }^{, 50}$ And yet, how exactly the statement "I feel like Charlie Coulibaly" "attacks" people or "incites hate," instead of criticizing an idea or concept, is unclear.

While these explanations try to draw clear, principled lines, they ultimately fail - in part because they do not account for the role of an unclear "public order" exception to speech protection, one that restricts or protects provocative speech depending on whether it suits the political will. French law "selectively protects the dignity of certain communities and minority groups more than others." ${ }^{, 51}$ In addition to the Dieudonné example, consider that, while a cartoon depicting a Muslim being shot while holding the Qur'an, drawn in reference to the massacre of 1,300 protestors against

American courts to restrict speech; on the contrary, it acts to ensure that other laws do not impede on constitutional free speech guarantees. See id.

45 Gerhart Husserl, Public Policy and Ordre Public, 25 VA. L. REV. 37, 42 (1938).

46 Bird, supra note 31, at 407.

47 Mike Wendling, \#FreeSpeechStories: France Accused of "Double Standards", BBC NEWS (Jan. 17, 2015), www.bbc.com/news/blogs-trending-30850879.

48 Id.

49 Id.

50 Carvajal \& Cowell, supra note 4.

51 James McAuley, There's a Model for How France Should Treat Its Muslims. It's How France Treats Its Jews, NEW REPUBLIC (Jan. 16, 2015), www.newrepublic.com/article/120796/reaction-charliehebdo-shooting-highlights-free-speech-disparity. 
Egyptian General Sisi's coup, did not result in any arrests, a sixteen-yearold was arrested for posting on Facebook a spin-off of the same cartoon, this time depicting the Charlie Hebdo director being shot down with a copy of the magazine in his hands. ${ }^{52}$

And unlike its approach to anti-Muslim speech, the French government cracks down on anti-Arab speech. In February 2011, French commentator Eric Zemmour was convicted of "provocation to racial discrimination" for declaring on television that "the majority of drug dealers are blacks and Arabs" and that employers "have the right" to deny them employment. ${ }^{53}$ And Brice Hortefeux, who once served as the Minister of the Interior, has been convicted of "racial insult" for comments caught on video regarding Arabic immigrants, and fined seven hundred and fifty euros. $^{54}$

Similarly, the French government prosecutes anti-Semitism aggressively. ${ }^{55}$ John Galliano, the head designer at Christian Dior, was fired and charged with "injure raciale" after a video of him making anti-Semitic remarks surfaced. French-Cameroonian comedian Dieudonné M'Bala M'Bala has been convicted seven times and fined various amounts for his anti-Semitic comments. ${ }^{56}$ Even Charlie Hebdo engaged in self-censorship: in 2008, the French satire magazine fired one of its most famous and oldest cartoonists, Siné, for writing an article considered to be anti-Semitic. ${ }^{57}$ And yet, when Siné wrote a piece in which he stated that he "could not bear Muslims" and that "when he saw a veiled woman he wanted to "kick her in the ass, $", 58$ there were no protests from the director of the magazine.

Unclear guidelines also accede too much power to the government. In addition to France's already-stringent laws on free speech, after the Charlie Hebdo attacks, the Justice Ministry issued new rules to prosecutors and judges for trying those who defended the attacks. ${ }^{59}$ Thousands of police and

52 Didier Fassin, In the Name of the Republic: Untimely Meditations on the Aftermath of the Charlie Hebdo Attack, 31.2 ANTHROPOLOGY TODAY 3, 4 (2015).

53 Scott Sayare, France: Commentator Convicted for Inciting Racial Bias, N.Y. TIMES (Feb. 18, 2011), www.nytimes.com/2011/02/19/world/europe/19briefs-France.html.

54 Richard Brody, Injure Raciale, NEw YORKER (Mar. 21, 2011), www.newyorker.com/culture/ richard-brody/injure-raciale.

55 David Remnick, The Shadow of Anti-Semitism, NEW YORKER (Jan. 13, 2015), www.newyorker.com/news/daily-comment/shadow-anti-semitism-france.

56 Maia de la Baume, A French Jester Who Trades in Hate, N.Y. TIMES (June 22, 2012), www.nytimes.com/2012/06/24/movies/dieudonne-french-comic-behind-the-anti-semite.html?_r=0.

57 Jason Burke, “Anti-Semitic” Satire Divides Liberal Paris, The GuARdian (Aug. 2, 2008), www.theguardian.com/world/2008/aug/03/france.pressandpublishing.

58 Fassin, supra note 52, at 4-5.

59 Elaine Ganley \& Jamey Keaten, New Issue of Charlie Hebdo Sells Out Quickly, YAHOO! NEWS (Jan. 14, 2015), https://news.yahoo.com/charlie-hebdo-sells-dawn-muhammad-cover-0802554 47.html. 
soldiers were deployed around the country, moving to quash any racist remarks or praise for terrorists by "detaining anyone who shows even verbal support for terrorism or racism and anti-Semitism." ${ }^{\circ 0}$ More than fifty people were arrested for defending terrorism over the two week period following the attacks, several of which were convicted under special immediate sentencing measures. ${ }^{61}$ Among those punished for inciting terrorism was a mentally ill man who declared, "They killed Charlie, I had a good laugh," a man who posted "[u]sing a pencil and using a Kalashnikov are the same" on Facebook; and the above-mentioned sixteen-year-old who reproduced on Facebook a cartoon that supported the terrorists. ${ }^{62}$ The French police even went as far as to detain and question an eight-year-old boy who said, "The French must be killed. I am with the terrorists. The Muslims did well, and the journalists got what they deserved." 63

One way to bring consistency to speech protections in France is to delineate the precise contours of the "public order" exception in the way international law suggests. ICCPR Article 19 requires a "specific" threat that is "direct[ly] and immediate[ly]"-rather than merely potentially — tied to the expression. The parallel incitement to imminent violence standard protects "the mere abstract teaching... of the moral propriety or even moral necessity for a resort to force and violence." ${ }^{64}$ These principles are widely applicable across various speech types, amenable to consistent application, and protective of a much broader range of speech.

\section{CONCLUSION}

The French government's reaction to the Charlie Hebdo attacks brought to the fore the vague, overbroad nature of French speech laws and their inherent potential for abuse. Its blatant double standard in punishing politically unfavorable speech highlights the need for clear guidance, and, more specifically, the usefulness of drawing the line where international law does: at incitement rather than provocation.

$60 \quad I d$.

61 France Arrests 54 for "Defending Terrorism" After Charlie Hebdo Attack, ALJAZEERA AM. (Jan. 14, 2015), www.america.aljazeera.com/articles/2015/1/14/france-charliehebdoarrests.html.

62 Didier Fassin, In the Name of the Republic: Untimely Meditations on the Aftermath of the Charlie Hebdo Attack, 31.2 ANTHROPOLOGY TODAY 3, 4 (2015).

63 Associated Press, Police Detain 8-Year-Old Who Backed Charlie Hebdo Attack, N.Y. PosT (Jan. 29, 2015), www.nypost.com/2015/01/29/police-detain-8-year-old-who-backed-charlie-hebdoattack.

64 Brandenburg v. Ohio, 395 U.S. 444, 448 (1969). 